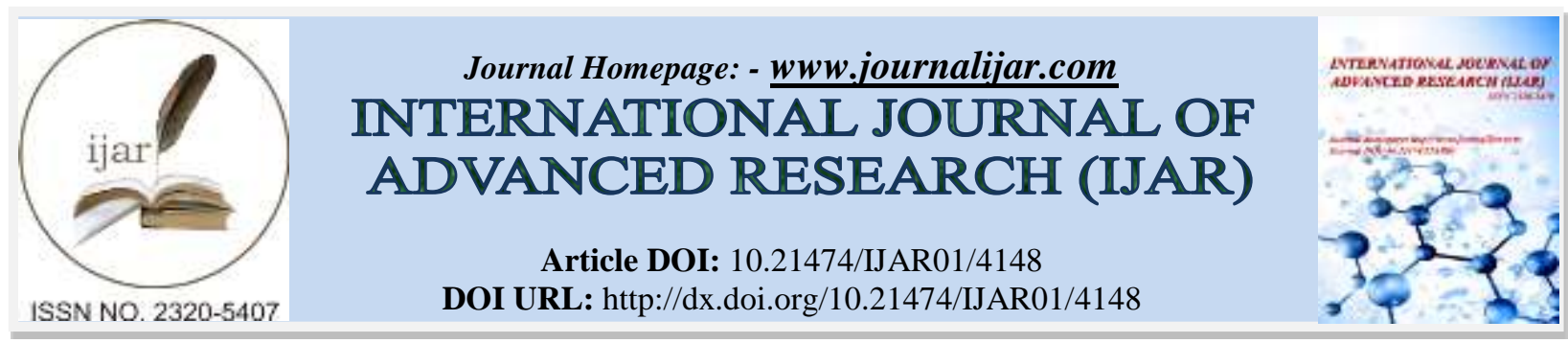

RESEARCH ARTICLE

\title{
ILLEGAL IMMIGRATION; A SOCIO-LEGAL ANALYSIS WITH SPECIAL REFERENCE TO HUMAN TRAFFICKING.
}

Bhavna Batra.

Assistant Professor, Amity Law School Amity University, Noida.

\section{Manuscript Info}

Manuscript History

Received: 04 March 2017

Final Accepted: 06 April 2017

Published: May 2017

\section{Abstract}

Illegal immigration is rampant and an issue of immediate concern for both, developed and developing countries. Conservative estimates reveal that there is a population of around 11 million irregular migrants worldwide. Fear that strangers can create problems as illegal immigrants is the reason a number of countries refuse visas to people from the third world. Illegal migration is a subcategory of international migration whose distinguishing feature is the legal status defined by the rules adopted by national governments and intergovernmental organizations. Illegal immigration creates a second class of citizenship. The benefits of economic development have clearly not trickled down to the marginalized sections of the society which is why millions of people still live below the poverty line. The hunger and poverty caused by this marginalization has resulted in women and children of poorer sections of society become more vulnerable to human trafficking.

Copy Right, IJAR, 2016,. All rights reserved.

\section{Introduction:-}

In India, social and religious practices also have been a big cause of trafficking. Part III of Article 23 of Indian Constitution $^{1}$ prohibits trafficking of human beings in the territory of India. There are additionally approximately twenty provisions in the Indian Penal Code, 1860 which deal with various aspects of human trafficking. But despite that, there is an inexplicable apathy onbehalf of the law enforcement agencies in implementing these laws.

Human migration has existed since times immemorial, the term immigration in the modern context relates to movement of people from one nation state to another, where they are not citizens. The term implies long term permanent residence by the immigrants. People migrate for a number of reasons such as economic, social, political, religious and personal factors. Attractive incentives for migration are called repelling factors while circumstances forcing migration are called attracting factors which happen to be the main reason for emigration from the country of origin. The push factor for a migration may be war, poverty, natural disaster etc. while a pull factor may be political stability, higher income, family reasons etc. The International Organization for Migration is the main intergovernmental organization in the field of migration. Formed in 1951 as the intergovernmental committee for European migration, its purpose was to help the people displaced during the Second World War ${ }^{2}$.Immigration Law

1 The Indian Constitution, 1950

${ }^{2}$ TulikaChakraborty, Immigration laws in India, http://legalservicesinia.com/article/article/immigration -laws-inindia-259-1.html. Visited on $21^{\text {st }}$ December 2012 
is the law which exclusively governs immigration in a nation. As far as foreign citizens are concerned Immigration Laws are related to nationality Laws of the nation; governing the matters of citizenship. International law regulatesImmigration laws. United Nations International Covenant on Civil and Political Rights is relevant ${ }^{3}$ in this regard.Statistics of illegal immigration reflect that back in the older times, people migrated towards the river basins because the region offered better economic prospects. In the post Industrial Revolution era economically welldeveloped cities have become immigration attractions. In the United States, economic progress, high standard of living and a high value of currency attracts legal and illegal immigrants. Illegal immigration in the United States from Latin America has been a major issue of concern. A large proportion of illegal immigrants belong to Asian countries of China, India, Japan and Korea, as well as the Middle East.

Free migration or open migration is that situation where people can and are able to migrate to whichever country they choose, free of substantial barriers. Although not the same, free migration is similar in spirit to the concept of free trade however both are advocated by Free Market Economists on the sole ground that economics is not a zero gum game and free market share is the best way to create a fairer and balanced economic system, thereby increasing the overall economic benefits to all parties concerned ${ }^{4}$.From a Human Rights perspective free migration can be said to complement Article 13 of the Universal Declaration on Human Rights: (1) Everyone has a Right to Freedom of Movement and Residence within the borders of each state. (2) Everyone has the Right to leave any country, including his own, and to return to his own country ${ }^{5}$.

Trafficking is a serious crime and a grave violation of human rights. A large number of men, women and children fall into the hands of traffickers both in their own countries and abroad. Almost every country in the world is affected by trafficking, whether as a country of origin, transit or destination for victims. UNODC, a guardian of the United Nations Convention against Transnational Organized Crime (UNTOC) and the Protocols thereto, assists States in their efforts to implement the Protocol to Prevent, Suppress and Punish Trafficking in Persons (Trafficking in Persons Protocol).”. According to Article 3 (1) of the Protocol against the Smuggling of Migrants by Land, Sea and Air, commonly referred to as the Smuggling of Migrants Protocol supplementing the United Nations Convention against Transnational Organized Crime ${ }^{6}$, smuggling of migrants is a crime defined under international law as "the procurement, in order to obtain, directly or indirectly, a financial or other material benefit, of the illegal entry of a person into a State of which the person is not a national or a permanent resident. Article 6 of the Smuggling of Migrants Protocol requires States to criminalize both smuggling of migrants and enabling a person to remain in a country illegally in order to obtain, directly or indirectly, a financial or other material benefit, as well as to establish as aggravating circumstances, acts, that endanger the life or safety and entail inhuman or degrading treatment of migrants. By virtue of Article 5, migrants are not liable to criminal prosecution for the reason of having been smuggled. It is therefore understood that the Protocol aims to target smugglers, not the people being smuggled $^{7}$. Salt and Stein in 1997 formally developed conceptualization of smuggling as a migration business ${ }^{8}$, even if one may find reference to this theory in earlier literature ${ }^{9}$. This new interpretation of the smuggling phenomenon had a great influence on academic circles. The concept was then borrowed by many academicians. Critically analyzing this concept, Herman stresses that the focus of expert discussions revolves around the notion of a migration industry and its professionalization in which migrants are seen as "products" and "people who aid migrants are called 'smugglers' and are portrayed as illegal 'entrepreneurs ${ }^{\text {' }}$ ".

${ }^{3}$ Ibid.

${ }^{4}$ The movement of people and goods linked ,BinodKhadria,BBCNews,April 132004

5 “MIGRATION WITHOUT BORDERS”,Essay on the free Movement of people ,Berghahn Books,Ed.2007

${ }^{6}$ United Nations, Treaty Series, vol. 2241, No. 39574.

${ }^{7}$ A short introduction to migrant smuggling", Journal ofUnited Nations Office on Drugs and Crime, Issue Paper, 2010; Neske, Matthias, "Human smuggling to and through Germany", International Migration, vol. 44, No. 4 (2006).

${ }^{8}$ Salt John and Stein Jeremy, "Migration as a business: the case of trafficking", International Migration, vol. 35, No. 4 (1997).

${ }^{9}$ KoserKhalid, "Negotiating entry into 'Fortress Europe': the migration strategies of 'spontaneous' asylum seekers", and Stein, "Migration as a business: the case of trafficking", p. 474.

${ }^{10}$ Herman ,Emma, "Migration as a family business: the role of personal networks in the mobility phase of migration”, International Migration, vol. 44, No. 4 (2006). 
Salt and Stein suggested treating international migration as a global business that has both legitimate and illegitimate sides. The migration business is conceived to be a system of institutionalized networks having complex profit and loss accounts including a set of institutions, agents and individuals each of whom stands to make heavy commercial gains. The model was divided into three stages: The Mobilization and Recruitment of Migrants; Their Movement Route; and Their Insertion and Integration into Labour Markets and Host Societies in destination countries ${ }^{11}$. Salt and Stein put their theory by citing the need and the idea of immigration controls in a new way, placing sharper focus on the institutions and vested interests involved rather than on the migrants themselves ${ }^{12}$. Aranowitz puts forth a similar view and claims that smuggling could not have grown to such proportions had it not been for the support of powerful market forces. The migration business has a dominating effect while analyzing smuggling trends in North America, South-East Asia and the Pacific region where smugglers are portrayed as "migration merchants" while the smuggled migrants are considered to be clients, paying for a service ${ }^{13}$. Equally, migrants may not use the word "smugglers" when they talk about the person who "helped" them". According to Aranowitz, the "Mother of All Snakeheads" - a major Chinese smuggler — is probably the symbol of the dual reality of smuggling of migrants, as she was considered as a saint for "reuniting families"

\section{Historical Background:-}

Illegal migration from Bangladesh into Assam needs to be viewed against the backdrop of past historical records, present realities and future designs. Migration into Assam has been taking place from the dawn of history. After the British annexed Assam, a large part of the population shifted from the South (Bengal, East Pakistan and now Bangladesh). This has been an ongoing phenomenon for over a century. This movement started for economic reasons but with the era of Independence itdeveloped communal and political overtones. After Independence, it acquired an international dimension and currently poses a grave threat to our national security.

The British developed the tea industry in Assam. They imported labour from Bihar and other provinces to work in the tea gardens. They encouraged Bengali Muslim peasants from present Bangladesh to move into Lower Assam so as to put the virgin land into cultivation. This set in motion a pattern which despite changed conditions has still been continuing to this day.In 1911, the British Government annulled the partition of Bengal. Assam was restored its status as a province and was placed under a Lieutenant Governor. The Assamese fear of losing their identity and being swamped by the Bengalis dates way back to this merger and even earlier. The fear had been aroused by the Bengali Hindus dominating the administration and professions, and the Bengali Muslims, altering the demography of the province. The Bengali Muslims were hard working peasants who occupied vacant land and put virgin areas under cultivation. With Constitutional Reforms, the country started advancing towards democracy, which is a game of numbers. The Muslim League now came up with its demand for Partition, on the basis of religion. The Viceroy, Lord Wavell wrote in the Viceroy's Journal, "The chief political problem is the desire of the Muslim Ministers to increase this immigration into the uncultivated Government lands under the slogan of Grow More Food but what they are really after, is Grow More Muslims."

Post Partition, an international border now separated the Assam and East Pakistan. Population movement from East Pakistan continued but it was mostly of Hindu refugees fleeing from religious persecution. Unlike the West, where refugee movement lasted for a few months only, in the East, this spread over several years and is still continuing. Hindu population in East Pakistan started declining steeply. In 1947 it was 27\%. By 1971 it reduced to $14 \%$ and then $10 \%$ in 1991. Along with Hindu refugees, Muslim infiltrators continued migrating into Assam for economic benefits. The movement of Hindu refugees into Assam got arrested due to anti-Bengali riots, as a result of violence in the wake of insurgency in the State. However, Hindu refugee movement from Bangladesh had continued to Tripura and West Bengal. Illegal migrants from Bangladesh into Assam are now almost exclusively Muslims. Failure to get Assam included in East Pakistan in 1947 remained a source of abiding resentment in that country.

\footnotetext{
${ }^{11}$ Salt and Stein, "Migration as a business: the case of trafficking", p. 479

12 Ibid., p. 485

${ }^{13}$ Schloenhardt ,Andreas, “Organized crime and the business of migrant trafficking: an economic analysis”, paper prepared for the Australian Institute of Criminology, Occasional Seminar Paper, Canberra, 10 November 1999;

${ }^{14}$ LiemptIlse van and DoomernikJeroen, "Migrant's agency in the smuggling process: the perspectives of smuggled migrants in the Netherlands", International Migration, vol. 44, No. 4 (2006)

${ }^{15}$ Aronowitz, "Smuggling and trafficking in human beings",p. 177.
} 
Zulfikar Ali Bhutto in his book, Myths of Independence ${ }^{16}$ wrote, "It would be wrong to think that Kashmir is the only dispute that divides India and Pakistan, though undoubtedly the most significant."

\section{Legal Distinction between Illegal Immigrants and Refugees:-}

The legal distinction between them is the former is self explanatory i.e. An illegal immigrant is one who is residing in the country illegally and refugees are persons who have migrated out of their own country out of fear of persecution founded on grounds of race, religion, nationality, colour etc. The 1951 United Nations Convention relating to the status of the refugees,as amended by the 1996 protocol defines refugees as "the persons who are living outside their country because of a well founded fear of persecution for reason of race, religion, nationality, membership of a particular social group or political opinion. ${ }^{17,}$

\section{Nationality and Citizenship Compared:-}

Nationality and Citizenship both capture fundamental principles of the contents and meaning of belonging ${ }^{18}$. The method of defining and alienating the English terms "nationality" and "citizenship" poses a major challenge to any enquiry pertaining to this field. Nationality is the traditional international legal term that refers to the link between an individual and a State ${ }^{19}$. International law leaves the question of nationality largely up to the individual country that is allowed to settle by its own legislation, the rules relating to the acquisition of its nationality and to confer that nationality by naturalization granted by its own organs in accordance with that legislation ${ }^{20}$. Citizenship implies "full membership" in a political community. Before the taste emerged as the predominant form of political organization, citizenship referred to memberships of small government units and the implied rights enjoyed by, as well as the duties imposed upon residents who were entitled to the status of citizen ${ }^{21}$. From a legal perspective, origin of the concept of Citizenship has been routed in domestic laws and has not traditionally been a concept of International $\mathrm{Law}^{22}$. Citizenship is a "contested truth" 23 that has in recent years enjoyed the attention of scholars from the across the disciplinary spectrum ${ }^{24}$. A contemporary understanding of citizenship refers less to an overarching status and more to a set of rights and obligations that the individual must negotiate across various levels of governance from concrete local communities and institutions, all the way up to higher levels of abstractions.

\section{Bonded Labour:- \\ An Introduction:-}

"It ought to concern every person, because it is a debasement of our common humanity. It ought to concern every community, because it tears at our social fabric. It ought to concern every business, because it distorts markets. It ought to concern every nation, because it endangers public health and fuels violence and organized crime. I'm talking about the injustice, the outrage, of human trafficking, which must be called by its true name -- modern slavery."

\section{President Barack Obama:-}

Most instances of forced labor occur when unscrupulous employers take advantage of gaps in law enforcement to exploit vulnerable workers. These workers are made victim to forced labor practices due to unemployment, poverty, crime, discrimination, corruption, political conflict and cultural acceptance of the practice. Immigrants are particularly vulnerable and often forced into labor in their own countries ${ }^{25}$. In the early stages, men were unsettled. They moved from one place to another in search of a livelihood. Search of a better standard of life pushed the settlements to the banks of rivers. At later stages, they learnt the art of cultivation as one of the requirement of

${ }^{16}$ Zulfikar Ali Bhutto, “ Myths of Independence” Oxford University Press, 1969

${ }^{17}$ United nations convention relating to the status of refugees, 28th July 1951,Art.1.2

${ }^{18}$ Hartnell ,Hellen Elizabeth, "Belonging: citizenship and migration in the European union and in germany",2,Berkly Journal of International Law 330 (2006)

${ }^{19}$ Ludvig,Alice," why should Austria be different from Germany? The two recent Nationality reforms in contrast", 13 German Politics 2004,499-500

${ }^{20}$ Nottebohm case ( Liech v. Guat), 1955 International court of justice ,20-21 (Nov. 29,1955)

${ }^{21}$ Shaw,jo , "the interpretation of European citizenship",61 Mroren law review 293 (1998), at 297

${ }^{22}$ Neuman,GeraldL.,Book Review,96,American journal of international law(2002) 514,514

${ }^{23}$ Baubook ,Rainer ,'recombinant citizenship",institute for advanced studies,Vienna political sciences serial no.67

${ }^{24}$ Sommers, M.r., "right ,relationality and membership: Rethinking the making and meaning of citizenship",19 law and social enquiry 63,64 (1994)

${ }^{25}$ www.state.gov/g/tip on 15 th march at $3 \mathrm{pm}$. 
livelihood and they shifted cultivation from one place to another place. With the coming of the Aryans in India, the Indian society was divided into four castes: i.e. Brahmins, Kshatriyas, Vaisyas and Sudras. The Sudra caste did not have property rights and educational and occupational choices. Even now, most of the bonded laborers belong to Sudra Community.

\section{Definition of Bonded Labour:-}

Bonded Labour means the culmination of the debtor-creditor relation into slave and master relation. For ages, the rich owners have been exploiting the so called debtors at every phase of life. To avoid the practice of bonded labour and to curb evil practices, the constitutional measures have become inevitable. The practice of bonded labour in India is known by different known names for example Vethi in Andhra Pradesh; Pannyals in Tamil Nadu; Jjeethe in Karnataka; Haris in U.P. Bonded Labour is a form of forced labour analogous to slavery such that if slavery is uncivilized then the civilized form of slavery is bonded labor. Generally bonded labor is the result of an agreement between a debtor and creditor wherein debtor pledges his only property i.e. his physique in the personal services on the creditor without, or for nominal remuneration in lieu of the satisfaction of the debt with interest for specific period or till debt is satisfied ${ }^{26}$.

\section{Bonded Labour and Forced Labour:-}

The enactment of the Bonded Labor System (Abolition) Act 1976, bonded labor which is a form of forced labour was prohibited. The Article 23 of the Constitution of India also prohibits the same. Similarly, slavery and unlawful compulsory labour were made criminal offences long ago, punishable under Sections 370, 371 and 374 of the Indian Penal Code. Article 23(1) prohibits traffic in human being, Begar and other similar forms of forced labour. Any contravention to this article shall be an offence punishable in accordance with law.

\section{Significance of The Bonded Labour Ordinance, 1975:-}

Even after the 28 years of inequalities, exploitation and oppression of the weaker section continued. On $24^{\text {th }}$ October 1975, the President of India promulgated an ordinance that was later legislated into an act called The Bonded Labour (Abolition) Act, 1976 prohibiting the Bonded Labour system in India in pursuance to Article 23 of the Constitution that prohibits Bonded Labour. As per the act, any amount of cash and/ or in kind either in written or in oral between debtors a creditor was not allowed. The debt owed by a person either directly or through his/her ancestors could not compel the person to be a bonded labourer.

\section{Trafficking of Illegal Immigrants for Bonded Labour:-}

The International Labour Organization's (ILO) made a knowledge based survey on trafficking in human beings consisting mainly of reports reviewing the implementation of relevant Conventions in member states. Traffickingrelated information was also obtained through numerous studies of the ILO International Migration Branch ${ }^{27}$. The growing international interest in the illegal movement and exploitation of human beings has led to new and innovative research within the ILO, covering various issues such as child trafficking ${ }^{28}$ irregular migration, and forced labour $^{29}$. However, the ILO's new research programme initiated under the ILO Special Action Programme to Combat Forced Labour (SAP-FL) has commissioned a dozen studies on trafficking and other forced labour outcomes of migration, and has also published training, legal, and other information material in this field ${ }^{30}$.

\footnotetext{
${ }^{26}$ Bandhuamuktimorcha v. UOI ,AIR 1992 SC 38 at pp.44

27 See, for example, Taran and Moreno-FontesChammartin (2003) and Taran and Geronimi (2002). For more information on migration, see http://www.ilo.org/protection/migrant/

${ }^{28}$ The International Programme for the Elimination of Child Labour has also commissioned a range of studies on child trafficking, which can be found at http://mirror/intranet/english/standards/ipec/.

${ }^{29}$ The term forced labourin this paper is understood to mean forced labour and services, as such it includes forced sexual services (sexual exploitation).

${ }^{30}$ Research includes Gao (2004) and Tiuoriuokanova (2004). Legal material includes ILO (2005), see http://www.ilo.org/forcedlabour.
} 
The ILO is particularly well placed to develop a better understanding of the labour dimensions of human trafficking. The bulk of the existing literature focuses on trafficking for sexual exploitation of women and children.

\section{Definitions and Methodologies:-}

Developing a definition of trafficking that is based on current legal understanding but at the same time not too legalistic is a first important step. Qualitative studies have helped in obtainingmore clarity on the definition which in turn has informed the framework for our quantitative research. International instruments have helped to clarify definitions but still there remains serious inconsistencies between different instruments as well as between terminologies used by individual researchers. The 2000 Palermo Protocol $^{31}$ to Prevent, Suppress and Punish Trafficking in Persons, Especially Women and Children, provides a comprehensive definition describing three key elements:

1. The activities that constitute human trafficking (recruitment, transportation, harbouring, receipt of persons);

2. The means being used (force, coercion, abduction, fraud, deception, abuse of power or of a position of vulnerability);

3. The purpose, which is exploitation (prostitution of others, sexual exploitation, forced labour or services, slavery or practices similar to slavery).

The key of the Palermo definition relates to the intention of the perpetrator. The problem with trafficking however is, intention, or Mens Rea is highly subjective and difficult to prove in court proceedings. The Palermo definition of trafficking is further complicated as there is no standard definition of exploitation. Forced labor has been defined in the ILO Convention No. 29 (1930) as: "All work or service that is exacted from any person under the menace of any penalty and for which said person has offered him voluntarily." There are two main elements in this definition: (1) menace of penalty, and (2) the notion of consent.

The ILO supervisory bodies have concluded that the worker's Right to Free Choice of Employment remains inalienable. Hence a worker must always have the possibility to revoke a previously made consensual agreement. In a second step, cases were classified according to the trafficking dimension of forced labour, using the following two variables:

1. Deceptive and/or coercive recruitment, and

2. Forced labour exploitation.

The recruitment mechanisms in forced labor are linked to the labour market in the destination country. This means that a migrant who has initially been smuggled across the border and was then recruited into forced labour would becounted as a trafficked victim. Where there was no connection between movement, recruitment, and final employment, migrant was referred to as a non trafficked victim of forced labour and not as a trafficked victim of forced labour. One should note that this is a sociological, not a legal distinction. In the second scenario, migrant workers who are or have been legal in the destination country for a certain period of time do not depend on an intermediary (either for the transportation, contacts to the employer, credit, etc.). Forced labour may not be the only outcome of trafficking, as perceived by the Palermo Protocol.

For the past two decades, Asia has been characterized by rapid growth of a market-driven intraregional migration. The end of the cold war, the onset of economic development in China, and the growing global market integration of the region, meant that the more developed parts of Asia, including Hong Kong SAR, Japan, South Korea, and Taiwan POC would now experience severe labour shortages. While none of these governments allow permanent settlement per se, the regional inflows of migrant workers have become firmly established in these countries. The countries of East Asia have fairly restrictive immigration policies especially towards the unskilled. Neither Japan nor South Korea allows unskilled foreign workers to hold even short-term jobs. These restrictive policies coupled with the government's incapacity to manage migration rendered the organization of migration in Asia largely to the private sector. Much of the earlier labour migration flows in Asia included unskilled men. However, starting in the 1990s, the large proportion of women in contract migration became one of the distinctive characteristics of migration in the region .In the mid-1990s about 1.5 million Asian women were working abroad both legally and irregularly ${ }^{32}$.The overall female migration in Asia increased during this period. By 2000, estimates showed that the

\footnotetext{
31 The Palermo Protocols are three protocols that were adopted by The United Nations to supplement the 2000 Convention against Transnational Organized Crimes (The Palermo Convention)

32 See, http://www.ilo.org/global/about-the-ilo/newsroom/news/WCMS_008072/lang--en/index.htm.
} 
number of female migrants surpassed male migrants in East and South-East Asia. Hence, approximately half of the migrants in East and South-East Asia are women.

In South Asia, the corresponding rate is 44 per cent although not all of these women are migrant workers. The flows of female migration show geographical and sectoral concentration. The majority of female migrants are from smaller countries like the Philippines, Indonesia, and Sri Lanka. The female migrants are employed predominantly in such unprotected sectors as entertainment and domestic services.Trafficking in women and children is considered to be increasing in the region. The routes, destinations, and modes of trafficking are well known and stories of corruption among public officials and local authorities are common. Trafficking presents a particular challenge to researchers as the identification of cases is far from obvious, even after the UN Convention against Transnational Organized Crime provided conceptual boundaries.

There is a certain pattern to the processes in which either legal male migrants or trafficked women are recruited, transported, and possibly exploited by sets of brokers in both the countries of origin and destination. Both labor migration and trafficking fall between two ends of the continuum, although the latter admittedly involves more illegal practices and exploitation. In addition, unlike smuggling this necessarily involves border crossings. Trafficking also includes internal movement of trafficked persons as per the UN Convention.

Furthermore, the difficulties of distinguishing trafficking from other forms of migration becomes even more diffcult when we consider the international flows of adopted children and brides who have been abducted from their communities. China is an example of this conundrum. Internal bride trafficking has been frequently reported while systematic research on these diverse forms of trafficking is sorely lacking.

Although some elements of smuggling and trafficking are similar, it is useful to make a conceptual distinction for analytical purposes: unlike smugglers, the trafficker has a vested interest in their victim's arrival, hence the payment is made after the victims have reached the fag end of the process i.e. she or he is about to be exploited. East Asian, countries with well-developed sex industries like Japan, South Korea, and Hong Kong SAR, are destinations for women from Philippines, Thailand and several other Commonwealth of Independent States (hereafter CIS) countries, Eastern European countries, and South American countries. Within China, a large number of women and children are trafficked into forced marriage. Infant boys are trafficked for adoption. Rural Chinese women and children in southern China are trafficked cross-border to work in the sex industry in Thailand and Malaysia.

\section{Trafficking in East Asia:-}

Main Issues:-

The reality of diversity in terms of trafficking typologies and different levels of organized crime involvement is appalling coupled with the varying degrees of consent and complicity.

\section{Scale and Routes:-}

Given the clandestine nature of the phenomenon, calculating estimates on the scale of trafficking is next to impossible. Direct and indirect indicators are available, including police records and the number of visas issued to those working in entertainment industries, useful in providing rough estimates of the possible scale of the trafficking in the region. China, according to a news-clip reported in Asian Migration News (2004), statistics from the Public Security Ministry of the Chinese Government show that between 2001 and 2003, the police resolved 20,360 cases of trafficking in women and children, arrested 22,018 traffickers, and freed 42,215 kidnapped women and children ${ }^{33}$. As for South Korea, the Government reported 100 cases in the years 2000 and 2001. Both Japan and South Korea have a visa category for entertainers. This has been widely known to be a legal channel that is abused for trafficking women for sexual exploitation. In Japan, the entertainment visa is authorized under the Immigration Control and Refugee Recognition law, while in South Korea it is made available through the provisions of the Departure and Arrival Control Act. In both cases, entertainment visa holders are barred from working as hosts or hostesses at establishments serving alcohol as well as those allowing for a direct contact with customers. Women entering Japan and South Korea on entertainment visas not only work in the sex industry but also overstay and become irregular migrants.

\footnotetext{
${ }^{33}$ Anne Marie Tavella, Sex Trafficking and the 2006 World Cup in Germany: Concerns, Actions and Implications for Future International Sporting Events, $6 \quad$ Nw. J. Int'l Hum. Rts. 196 (2008).http://scholarlycommons.law.northwestern.edu/njihr/vol6/iss1/8.
} 
According to Immigration Bureau Statistics, Japan approved 118,000 applications in 2001, and 123,322 in 2002 under the entertainment visa category. In both years $60 \%$ of the applicants were Filipinas. The equivalent for South Korea is 5,092 in 2001 and 5,285 in $2002^{34}$. The extent to which female entertainers are involved in the sex industry and suffer from human rights abuse and labour exploitation has not been established.

\section{Forms of Exploitation: Comparison within Countries:-}

Rampant trafficking in rural China is often attributed to a decade-long one-child policy that resulted in gender imbalance and a universal expectation to marry. Men in communities experiencing severe shortages of women are under immense pressure to find a bride. When they cannot afford to pay the high bride price for local women, they readily resort to purchasing brides kidnapped from other areas. The purchase of trafficked women thus provides for a more cost-effective solution for men in the marriage which in turn yields a high profit for traffickers and middlemen.Vietnamese women are trafficked to southern Chinese villages. Those fleeing North Korea are deceived or encouraged to marry rural Chinese men in the north-eastern provinces. In traditional East Asia and apparently still in some remote rural villages in China, the consent to a marriage proposal has not been that of a bride-to-be. Givn the seemingly voluntary participation in the sex industry, the question remains whether or not a women's willingness to marry a man chosen by her parents counts as genuine consent in a culture where women do not choose their own husbands. Even at a stance when the concept of profit is considered, it still is not straightforward as to whether or not the difference between paying a traditional bride price and buying a wife is wide enough to classify the former as a cultural practice.

\section{Causes of Trafficking in relevance to Bonded Labour:-}

Underlying the seemingly growing problem in East Asia, are the common push and pull factors reported everywhere else. Factors that render persons, especially women and children, vulnerable to trafficking are development processes that marginalize women, particularly from employment and education, gendered cultural practices, gender discrimination, and gender-based violence in families and communities. Restrictive immigration policies and lawscontribute to the development of underground migration channels by generating a market for trafficking. Indeed, the migration policies and laws of both Japan and South Korea are considered restrictive and conservative in a sense that both countries limit their intake of foreigners as long as the flow is considered temporary.In South Korea, the presence of US military bases has also drawn considerable amount of attention from both within and outside the country. A close tie between sex trade and militarization in South Korea is one of the recurrent themes in all forms of writings about the phenomenon within and without the country. The militarization of Korea and its ties to the development of the sex industry began during the Japanese colonial rule (1910-1945) of the peninsula, when prostitution was officially recognized, licensed, and even developed on a nationwide scale. This trend continued right from the end of Japanese rule to the establishment of US military bases later on.

\section{The Face of Slavery of Illegal Immigrants:-}

Although rarely found in urban Bangladesh, Bonded Labor is common to rural areas. While in Urban cities, workers are paid a daily or fixed wage, the rural workforce mostly has to make verbal arrangements for wages, which are often manipulated by unscrupulous landlords and loan sharks, known as Mahajans. Still another way to become bonded is being forced to take out a loan due to a temporary financial crisis, often caused or aggravated by a poor harvest or a family emergency. Once person enters into the trap of bonded labor, long work hours with little or no pay for more often than not, seven days a week, becomes a commonplace. Many workers, mostly women and children, end up as domestic servants, working in conditions that resemble servitude. They suffer physical abuse, sometimes resulting in death and are often exposed to inhuman treatment.

In 1972, Bangladesh ratified both ILO Convention No. 29 (1930); The Forced Labour Convention and ILO Convention No. 105 (1957); The Abolition of Forced Labour Convention ${ }^{35}$. The law prohibits forced or bonded labour and the Factories Act and Shops and Establishments Act provide for inspection mechanisms to strengthen laws against forced labour. "Forced labour has been present in Bangladesh for centuries. After the liberation of

\footnotetext{
${ }^{34}$ Data and Research on Human Trafficking: A Global Survey, Vol.43 (1/2) of 2005, International Organisation for Migration. See, http://lastradainternational.org/lsidocs/282\%20IOM\%20survey\%20trafficking\%20(Global).pdf.

35 The Two chief Conventions aimed at eradicating Forced Labour are the ILO Conventions 29 (1930) and $105(1957)$
} 
Bangladesh, it changed its form and has taken the new face of various 'contracts' associated with loans taken by poor farmers from the usurers,"

\section{Bonded Labour Trafficking Process:-}

Amongst the multiple stages of the trafficking process one of them is that the entire process is carried out by a number of people along the route from the countries of origin to destination. In the region, a formalization of the entire process, especially recruitment, has been reported. In the most immediate level in the countries of origin, there are people who can identify potential victims. They tend to belong to the same social network as the victims, either through family lines or other social groupings. The more or less formal recruitment is quite usual in the countries of origin such as Philippines and Thailand, where young women are recruited by either or both local and Korean/Japanese recruiters. Hyperbolic job advertisements are common promising jobs abroad as escorts, servers, and dancers, or otherwise as art performers.ILO report observes that with the growing urban migration of rural young women there coincides a tendency of trafficking with false promises of work. These women end up being forced to provide sexual services in richer neighboring countries. In the past, the internal trafficking for marriage in China from kidnapping to (re)selling trafficked persons was carried out by independent operators. Now, organized crime gangs overseeing the entire process are increasingly dominating the trade. The transportation stage seems to be one of the least studied stages of the trafficking process, as far as the materials on East Asia is concerned.

The standard of criminal organization's involvement in sex trafficking in East Asia seems rather high. The organized crime group, called yakuza, is believed to have initiated the importation of foreign women to Japan in the 1980s, when demand for sex tours had declined in response to the loud protests by feminist groups in the destinations of such tours, namely, South-East Asian countries and South Korea ${ }^{36}$. Penetration of the crime group into civil society and government has limited the Government's ability of taking decisive actions against trafficking. There has been some shift in the Japanese legislation, allowing the police to criminalize some of the yakuza activities. In spite of the deep involvement of such criminal organizations as yakuza in trafficking of women in East and South-East Asia, it is incorrect to assume that trafficking in East Asia is entirely handled by international criminal gangsters. In South Korea, most companies involved in employing foreign entertainers such as the recruiting agencies, entertainment management companies and clubs are run like a family company. Division of labour among them exists only on paper while work in reality is shared by closely related people. Snakehead networks and Normal Social Networks are mediums to propagate trafficking. Given the complex nature of human smuggling and trafficking in China, a government crackdown alone may not be a sufficient solution. This overlap of networks also means it is unrealistic to expect human smuggling and trafficking to be eradicated soon. Instead, the immediate priority for governments and international agencies should be to reduce the human suffering accompanying smuggling and trafficking.

\section{Types of Immigration:-}

The phenomenon of immigration carries several different definitions. In common parlance, immigration is the movement of people from their native country to another country with intent to settle down, for the purpose of a livelihood. Immigration can be segregated into 3 domains, namely, legal, illegal and domestic.

1. Legal Immigration:A legal immigration is a movement of a person from his native country to a foreign country in search of livelihood and an intention to settle down, with prior and proper permission (valid visa, passport or citizenship) from the government.

2. Illegal Immigration:Illegal immigration is the movement of a person from his native country to foreign country, with intent to find a livelihood and settle down without the permission of the government. Illegal immigration is an offense with legal consequences from the state's criminal code.

3. Domestic Immigration:Domestic immigration is the movement of people from an economically backward region of the country to another developed and economically well off region of the same country.

\section{Legal and Political Status:-}

Permission to stay in a country legally may be decided by quota systems or point systems. It may be based on consideration such as family ties (with exceptions to political refugees). Illegal immigrants without proper legal status have no valid identification documents such as identity cards and have reduced or no access to public health system, proper housing, education and banks. This may result in the creation or expansion of illegal underground forgery to provide for documentation.

\footnotetext{
${ }^{36}$ David E. Kaplan and Alec Dubro, “East Asia: The Yakuza Expand,” in Yakuza: The Explosive Account of Japan's Criminal Underworld, New York: Macmillan Publishing Company, 1986,
} 
Unauthorized immigrants are especially popular with many employers because they can pay less than the legal minimum wages or provide unsafe working conditions, secure in their knowledge that hardly any of the unauthorized workers will report the abuse to the authorities. The freedom of movement of an individual within national borders is secured by the Constitution or Country's human rights legislation but these rights are restricted to citizens and exclude all others. According to Article 13 of The Universal Declaration of Human Rights ${ }^{37}$, fundamental human rights are violated when humans are forbidden to leave their own country

\section{Factors for Illegal Immigration:-}

Repelling Factors:-

- Internal war and annexation

- Internal armed conflicts such as civil war, secession, dissolution and revolutionary cops or other internal national or ethnic conflict

- Totalitarian regime with political persecution or genocide

- Forced settlement

- Discrimination against minorities

- Discrimination against majorities

- Terrorism

- Other violation of human rights

- Poverty and hunger

- Unemployment or low permanent wage levels

- Natural disaster

- Ecological devastation

Attracting Factors:-

- State protection of the subsistence level

- Unsaturated labour market with higher level wages

- Opportunities for higher education or advanced training

- Overall economic prosperity

- Family reunion

- Striving for luck and cognition

- Political stability

- Maintenance of the rule of law

- Democracy

- Pluralism

- Effective protection of human rights

- Habitable living space

Reasons of Illegal Immigration:-

Social Reasons:-

- Over Population:When population growth exceeds the carrying capacity of an area or environment, it results in overpopulation. Increase in human population can cause problems of pollution, water crisis and poverty. World population has grown from 1.6 billion in 1990 to an estimated 6.7 billion today.

- Family Reunification:Some illegal immigrants seek to live with loved ones, such as a spouse or other family members. Family reunification visas may be applied for by legal residents/naturalized citizens to bring their family members in. However, these visas may be limited in number and subject to yearly quotas resulting in more illegal immigration.

- War and Asylum:Illegal immigration may occur from the desire to escape civil war or repression in the country of origin. Non economic repel factors includes persecution, frequent abuse, bullying, oppression and genocide and risks to civilians during war. Political motives traditionally motivate refugee flows to escape dictatorship for example. It is important to note that the status of illegal immigration may coincide with or be replaced by

\footnotetext{
${ }^{37}$ Article 13 of Universal Declaration of Human Rights states: (1) Everyone has the right to freedom of movement and residence within the borders of each state.(2) Everyone has the right to leave any country, including his own, and to return to his country.
} 
the status of asylum seekers for emigrants who have escaped a war or repression and have illegally crossed to the other state. If they are recognized as legitimate asylum seekers by the destination state, they will then gain legal status. However, there may be numerous political asylum seekers in a destination state who are unwilling to apply or are in the process of applying for asylum status, and hence are categorized as "illegal immigrants"

\section{Economic Reasons:-}

- Economic and Labour Market: The net flow of illegal immigrants is entirely from the countries of lower socioeconomic levels to thoseof higher socioeconomic levels- and particularly from developing countries to developed countries. The most common motivation for illegal immigrants is the pursuit of greater economic opportunities and the quality of life in the destination state ${ }^{38}$. The new proposed economic models based on a cost benefit framework have varying considerations and degrees of complexity.Under the basic cost/benefit argument for illegal immigration, potential immigrants believe the probability and benefits of successfully migrating to the destination country are greater than the costs. These costs may include the restrictions of living as an illegal immigrant in the destination country, being forced to leave family and ways of life behind, and the probability of being caught and the resulting sanctions ${ }^{39}$.

- Neo Classical Model: The Neo Classical Economic Model looks only at the probability of success in immigrating and finding employment, and the increase in real income an illegal immigrant can expect. This explanation would account for the differential in economic factors between the two states, including how much of a "pull" the destination country gaps in terms of better paying jobs and improvements in quality of life. It can also be described as a "push" that comes from negative conditions in the home country like lack of employment or lack of economic mobility.

- Trade Liberalization: In recent years, developing states are reaping benefits of globalization by liberalizing trade. Rapid opening of domestic markets may lead to displacement of a large number of agricultural or unskilled workers who are more likely to seek employment and higher quality of life as illegal immigrants. As observed in the case of the North American free trade associations that rendered the Mexican farmers impoverished as they were unable to compete with higher productivity of US subsidized agriculture.

- Poverty:Economic models do not necessarily imply that illegal immigrants are always impoverished by standards of the home country. The poorest classes in a developing country may lack the resources needed to cross illegally or the connections of friends/family already in the destination country. The increase in poverty, especially when associated with immediate crisis, can increase the likelihood of illegal immigration.

\section{Conclusion:-}

Illegal immigration revolves around those voluntary transactions that are supposed to benefit the immigrant, his employer and the third party. The main intention behind illegal migration flows is economic in nature; people move across borders because of the income differentials, in the hope of a more gainful employment. The illicit status of migrants also has consequences in mechanisms of cross-border movement and personal position of migrants. In other words, illegal migration cannot be separated either from the larger dynamics of the global economy nor the policies pursued by governments. Thus, although legal and illegal immigration differ in many crucial respects, they are both located at the interface of international economic and political systems. A politically motivated approach to human smuggling would regard people as commodities; people are moved illegally for a payment across borders because they have profit value for the smuggler whose start-up costs in the business are small.

The national borders continue to restrict international migration, however economic globalisation has only fuelled migration. Trafficked population has a high demand in the recipient country, primarily to fill gaps in the employment structure that needs cheap, irregular labour. In addition, the migrants turn themselves, often voluntarily, into transportable commodities because they expect to negotiate in the target country, a better price for their work. This creates a growing 'migration business' that has both legal and illegal elements. Yet, illegal immigration and human smuggling, and even trafficking, are interrelated and result in a 'terrible paradox'. The problem lies in the paradox that the stricter the enforcement of laws of immigration against the illegal entrants, the more sinister are the forms of criminality are used in human trafficking to overcome the barriers needed for making a profit. Ultimately, the intensity of violence associated with the smuggling of human bodies and body parts has increased because of the 'aggressive extension of market values on the bodies of the vulnerable'.

\footnotetext{
${ }^{38}$ Sommers, M.r., "right, relationality and membership: Rethinking the making and meaning of citizenship",19 law and social enquiry 63,64 (1994)

${ }^{39} \mathrm{http}$ //digitalcommons.ilr.cornell.edu/articles/256. Accessed on January 24,2013
} 